\title{
ANALYSIS OF SOLAR POTENTIAL OF ROOFS BASED ON DIGITAL SURFACE MODEL
}

\author{
M. Gorički ${ }^{1}$, V. Poslončec-Petrić2,*, S. Frangeš² ${ }^{2}$ Ž. Bačić \\ ${ }^{1}$ Tapaprojket d.o.o., Zagreb, Croatia - martingoricki@gmail.com \\ ${ }^{2}$ Faculty of Geodesy, University of Zagreb, Croatia, - (vesna.posloncec, sfranges, zbacic)@geof.hr
}

KEY WORDS: smart city, 3D models, digital surface model, solar potential of roofs

\begin{abstract}
:
One of the basic goals of the smart city concept is to create a high-quality environment that is long sustainable and economically justifiable. The priority and concrete goal today is to promote and provide sustainable sources of energy (SSE). Croatia is rich with sun energy and as one of the sunniest European countries, it has a huge insufficiently used solar potential at its disposal. The paper describes the procedure of analysing the solar potential of a pilot area Sveti Križ Začretje by means of digital surface model (DSM) and based on the data available in the Meteorological and Hydrological Service of the Republic of Croatia. Although a more detailed analysis would require some additional factors, it is clear that the installation of $19,6 \mathrm{~m} 2$ of solar panels in each household could cover annual requirements of the household in the analysed area, the locality Sveti Križ Začretje.
\end{abstract}

\section{INTRODUCTION}

According to the data provided by Organization of United Nations (UN), (UN 2014) in the 50-ties of the last century, $29 \%$ of the world population lives in the cities. This percentage has today reached about $50 \%$, and it is estimated that even $70 \%$ of population shall live in the cities until 2050. This percentage is even greater in Europe and reaches even $80 \%$ (UN 2014). Referring to the Republic of Croatia, it is estimated that the number of urban population will rise by 766000 , i.e. $43,4 \%$ (UN 2015).

Referring to such growth, the activities related to the solution of infrastructural problems in cities are focused more and more on energy and energy efficiency, public illumination, water supply and sewers, traffic and, of course, environmental impact. The growth of city population has encouraged the development of new city management concepts of smart cities. The development of information and communication technology made it possible to implement those new concepts for the purpose of their sustainable development (Poslončec-Petrić et al 2016a). The energetic efficiency and sustainability represent one of the greatest challenges in modern city management, and it can hardly be possible to manage and plan modern smart cities without high-quality $3 \mathrm{D}$ spatial data and models.

\section{3D MODELLING IN THE DEVELOPMENT OF SMART CITIES}

Until recently, 2D and 2.5D models were quite sufficient for all kinds of planning, but the development of computer technology has made 3D models more available and easier to work with than before. $3 \mathrm{D}$ models make planning in urban areas, in the fields of energy and noise management (Poslončec-Petrić et al 2016a), telecommunication, risk management easier (Dimova, 2010), provides easier orientation in space, which provides simpler and better planning of areas and better space perception and also easier planning of smart cities with higher quality (Protić et al, 2014).

3D models of the existing situation provide easier preparation and visualisation of future space concepts that may attract investors. 3D model intended for professional users must be focused on accuracy (geometric and attribute) and should have a necessary level of details included, and 3D model intended for general population (tourists, investors, property buyers, etc.) should be visibly impressive.

\subsection{Structures of 3D models intended for planning of smart cities}

When we speak of 3D models, we most often think of digital terrain models (DTM), digital building models (DBM) and digital surface models (DSM) (Figure 1).

Digital terrain model (DTM) is a set of points on the Earth surface with the spatial coordinates convenient for computer processing (Frančula 2004). It is a set of points and geometric elements determined with respect to position and height that represent land surface and a mathematical model computed with them, as well as surfaces (Frančula and Lapaine 2008).

Digital building model (DBM) is created on the basis of the data gathered about the built objects, and it can be best described as a set of individual 3D objects that are not mutually connected (Cetl et al 2013).

Digital surface model (DSM) is a continuous surface that differs from DRM in the fact that it is possible to attach more than one height to a point, i.e. it is possible to present perpendicular elements on the surface like buildings, steep rocks, etc. DSM is created by combining DRM and DBM (Figure 1).

Corresponding author 


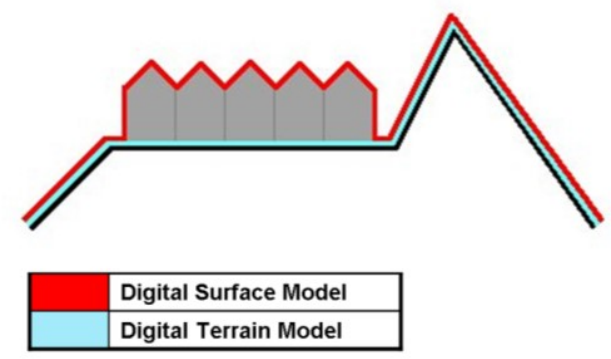

Figure 1: The difference between Digital Terrain Model (DTM) and Digital Surface Model (DSM) (Cetl, 2013)

\subsection{Production of 3D model of the pilot area}

Sveti Križ Začretje is a small place in the north-west part of the Republic of Croatia with 6619 inhabitants. It is located on the plateau of a small hill in the middle of alluvium valleys of the river Krapinčica and its tributaries Šemnica and Pačetina. It is located along the highway Zagreb - Macelj (Slovenia) in the vicinity of the towns Zabok and Krapina. It is excellently connected with Zagreb, the capital and the largest economic and cultural centre of the Republic of Croatia. All mentioned characteristics highlight the potential of this area to become a smart city and to have the smart-technology introduced into its management, which is why it has been selected as a pilot area in this analysis.

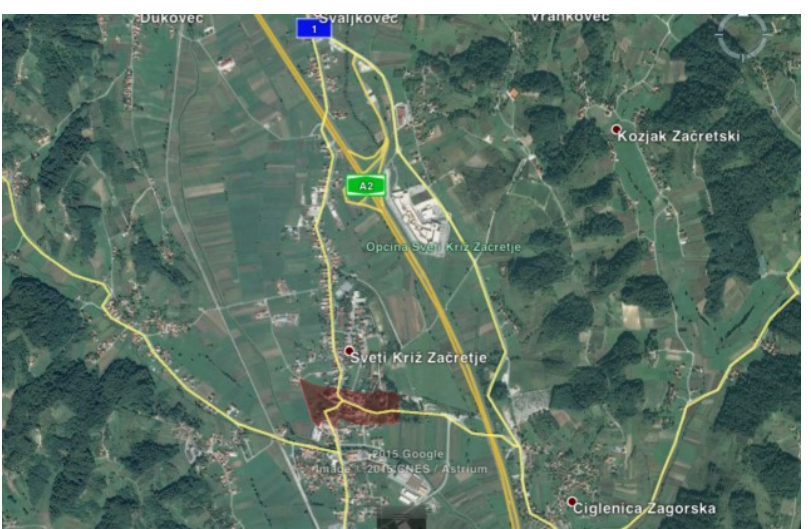

Figure 2. Sveti Križ Začretje

Within the frame of the diploma thesis made by Martin Gorički (Gorički 2015), a 3D model of Sveti Križ Začretje was made at the Chair for Cartography of the Faculty of Geodesy, University in Zagreb. The field measurements were made with the unmanned aerial vehicle DJI INSPIRE 1 and RTK device Topcon Hiper SR. The programmes Photoscan and AutoCAD Civil 3Dwere used for data processing, and the automatic creation of geometry was made from the point cloud with the programme VRmesh-survey. The resolution of the produced DSM is $0,155 \mathrm{~m} / \mathrm{pix}$, and point density is 41.85 points per $\mathrm{m}^{2}$ (more: Gorički 2015).

Based on the obtained data, photorealistic model was made with Photoscan and AutoCAD Civil 3D, that was published on Web by means of the on-line service Sketchfab, and it is available at: https://sketchfab.com/models/2b7a81 f0b91240849d36b795b3ed bbdc (Figure 3).
The application of such models is diverse, from promotions in tourism and publications of that kind (Figure 3) to the application in spatial planning, urbanism, environmental protections, etc. (Gorički 2015, Poslončec-Petrić et all 2016b, Dimova, 2010).

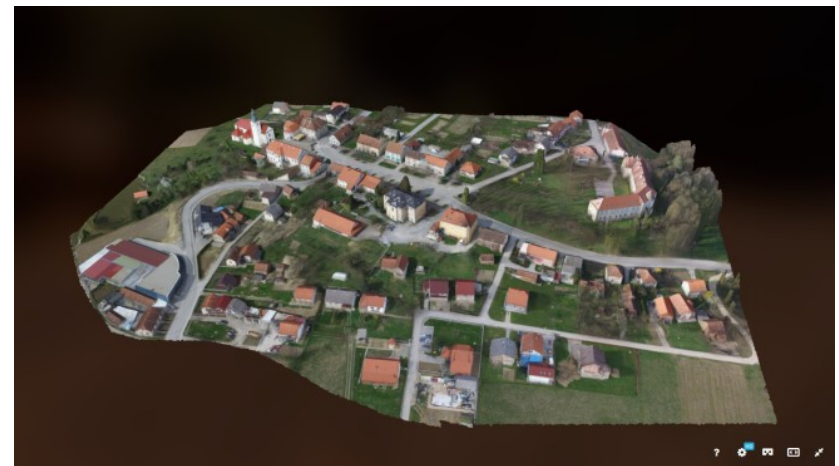

Figure 3. Photorealistic 3D model of Začretje published on Web (Gorički 2015)

\section{SOLAR POTENTIAL OF ROOFS}

The energetic efficiency is one of 5 goals specified in the European Development Strategy 2030, and it is related to the energetic sustainability and climate changes. The goals for the year 2030: to reduce the emission of glasshouse gasses by $40 \%$ in comparison with the levels measured in 1990, to generate at least $27 \%$ of consumed energy from sustainable sources, and to save at least $27 \%$ in energy consumption compared to the "business as usual" scenario (EC 2017).

Sustainable sources of energy (SSE) are the sources of energy that come from nature and can be renewed. They are used more and more today because they do not pollute the environment, and most often, the energy of wind, sun and water is used. The Republic of Croatia is rich in pure natural resources, especially sun energy. Although it is one of the sunniest European countries, it is still almost the last in the list of European countries using solar energy (Wikipedia 2017). The usage of sustainable sources of energy makes a country energetically highly independent and opens numerous work places apart from providing environmental and climate protection.

The analysis of the solar potential was made for the modelled area, and based on DSM, it is possible to calculate the savings in electric power after installing the solar panels in the households of Sveti Križ Začretje (Gorički, 2015).

\section{ANALYSIS OF SOLAR POTENTIAL OF ROOFS BASED ON DIGITAL SURFACE MODEL}

The analysis of solar potential based on DSM for the selected pilot area was made in the programme SAGA GIS. SAGA GIS is an open-code programme used to make spatial analyses, and the fundamental base for making this analysis is DSM. Input parameters for the analysis of solar potential of roofs were the following:

- Geographic location of the analysed area,

- Power constant of solar radiation in $\mathrm{W} / \mathrm{m} 2$,

- The time period in which we need to know the quantity of solar radiation and 
- Atmosphere heights and the pressure of water vapour in the air.

The values that reliably indicate the situation in the test area were taken to present the solar radiation constant, atmosphere height and the pressure of water vapour. Atmosphere height refers to height of troposphere at the location of pilot area as it can vary from $7 \mathrm{~km}$ to $20 \mathrm{~km}$ depending on different locations on earth. Referring to modelled area, these values are the following: solar radiation constant $1367 \mathrm{~W} / \mathrm{m} 2$, atmosphere height $12000 \mathrm{~m}$ and the pressure of water vapour in the air 10 mbar. Apart from the above-mentioned, it is necessary to define the time resolution of the analysis that determines the length of the time interval between the sun positions on the basis of which the analysis is performed. In the case of our analysis, the time resolution was 30 minutes (Gorički 2015). Based on the mentioned parameters and DSM, SAGA GIS generated the raster that contains the data about the quantity of sun radiation. The obtained results are indicated in the energy unit and energy per area $(\mathrm{kWh} / \mathrm{m} 2)$.

The performed analysis is rather demanding and depends on the time period that it is done for, as well as on the computer configuration. In our case, the requested time period was the whole year.

The obtained intensity of solar radiation for the area of the locality Sveti Križ Začretje was calculated for April (Figure 4), July (Figure 5) and December (Figure 6), as well as on annual basis (Figure 7). The obtained intensity of solar radiation is indicated in $\mathrm{kWh} / \mathrm{m} 2$.

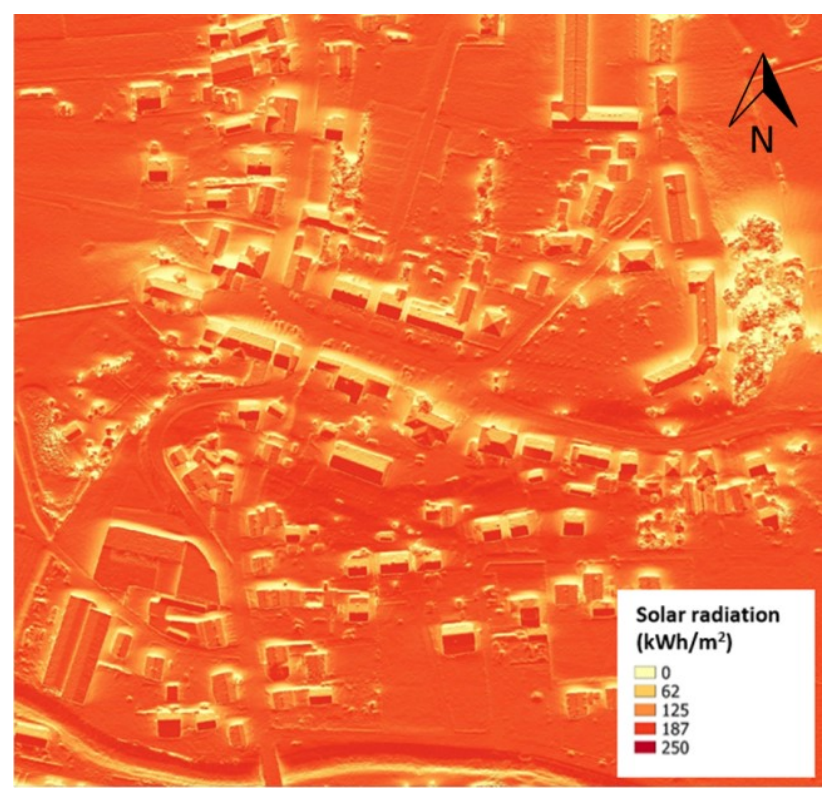

Figure 4. Solar potential of the test area in April

If we observe the figures 4,5 and 6 , it can be seen that the surface inclined to the south receives the largest quantity of solar radiation in April (Figure 4), in July, horizontal or approximately horizontal surfaces that are not covered by other objects receive the largest quantity of solar radiation. Solar potential is the largest in July and amounts up to $230 \mathrm{kWh} / \mathrm{m}^{2}$ (Figure 5).

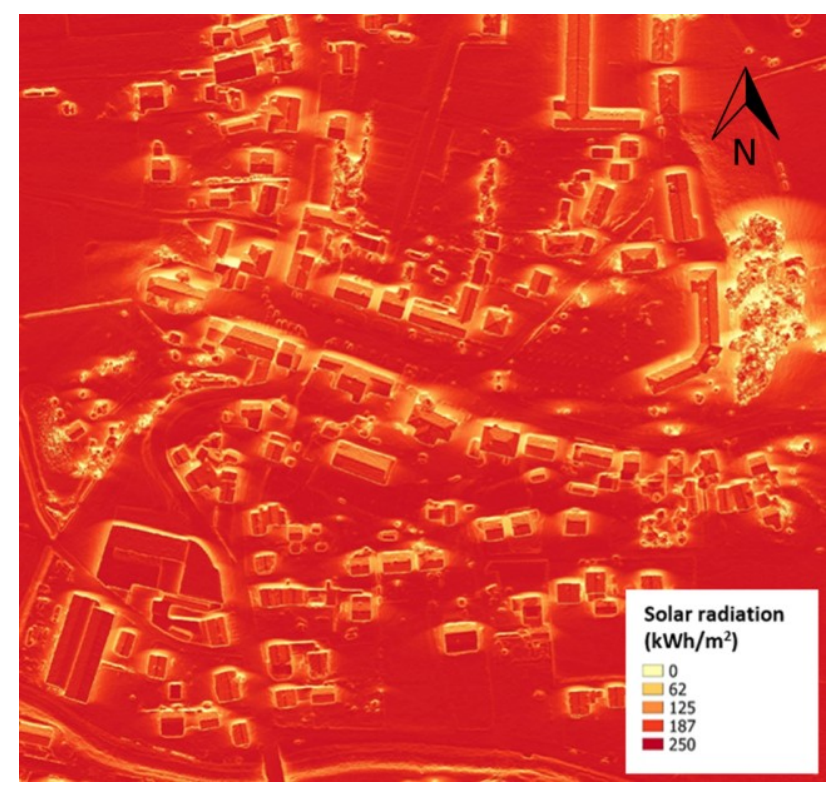

Figure 5. Solar potential of the test area for July

In December, the solar radiation is of a very small intensity on all surfaces (Figure 6). Only the roofs inclined to the south can be pointed out, however, the radiation there does not exceed 80 $\mathrm{kWh} / \mathrm{m}^{2}$, which is very slightly compared to July and April.

It should be mentioned that it was presumed in the performed analysis that a year has 365 sunny days. It is, of course, not realistic, but, since we deal here with a very small area, it can be considered that the same climate conditions are valid at the same time for the entire area (Agugiaro, G. et al 2012).

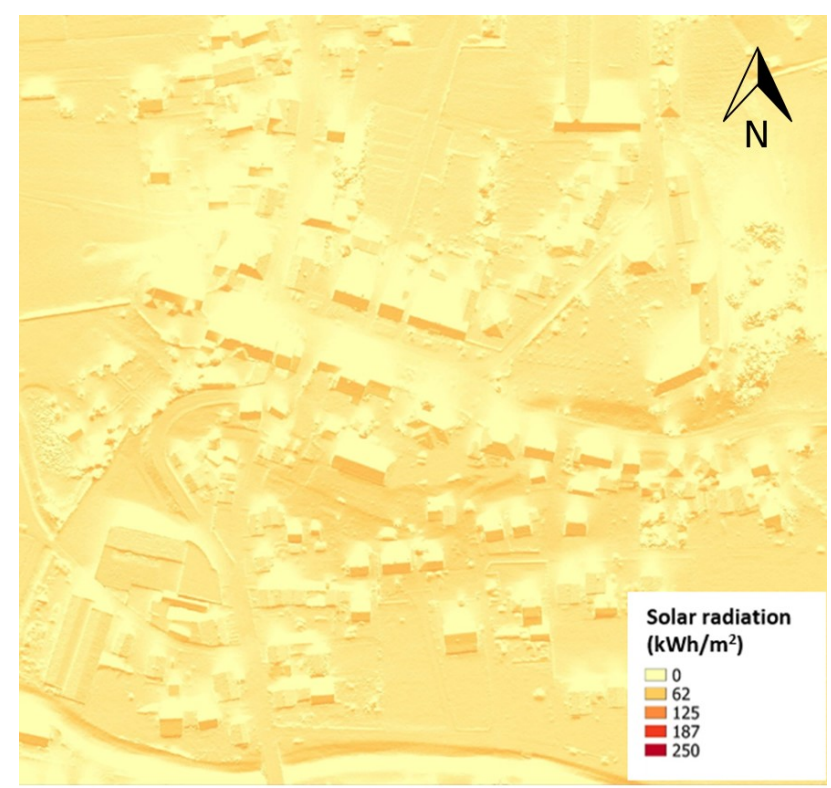

Figure 6. Solar potential of the test area for December 


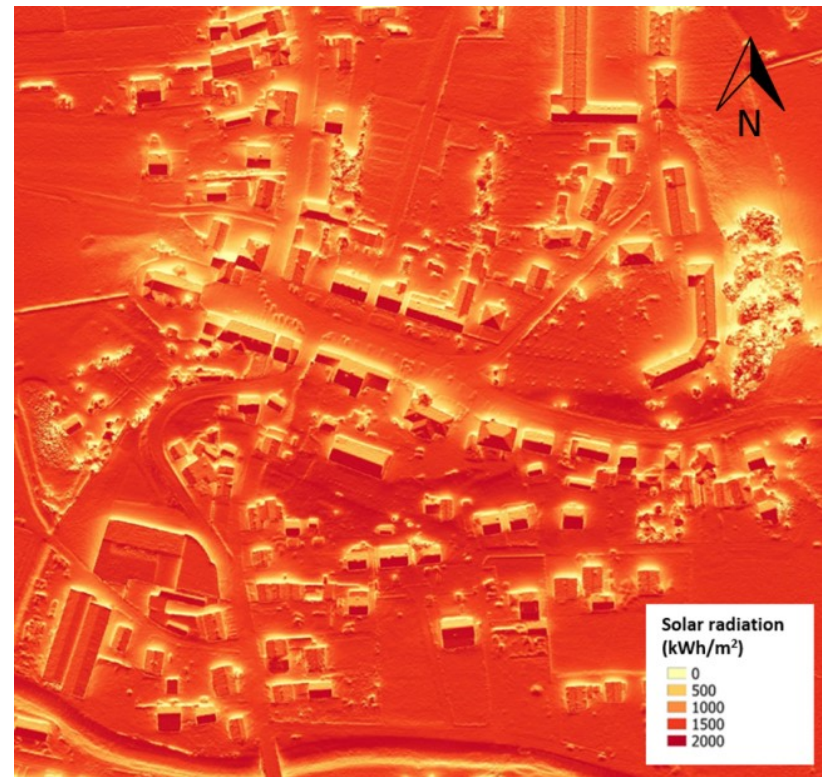

Figure 7. Solar potential in the test area for the whole year

The solar potential of the pilot area at the annual level is presented on Figure 7. At first sight, this figure is very similar to the solar potential of the observed area in July (Figure 5.). The roofs inclined to the south are the surfaces that receive the largest quantity of solar radiation being about $1900 \mathrm{kWh} / \mathrm{m}^{2}$ at the annual level what was readout from generated geo tiff inserted in Qgis software by hovering mouse over south oriented roofs. Although these figures seem rather big at the first sight, the real energy that can be received at the annual level from the solar radiation is much smaller.

\section{PROFITABILITY OF INSTALLING SOLAR PANELS AT THE PILOT AREA}

Since we are familiar with the solar potential of the pilot area, we would like to find out which amount of real energy can be obtained annually from the solar radiation.

For this calculation, we also needed the official data of the Meteorological and Hydrological Service of the Republic of Croatia (DHMZ) that is responsible for the generation of meteorological, hydrological and related information. DHMZ provided for us the data about the average number of sunny hours in a year obtained by the observations in the period from 1993 until 2010 (Figure 8) in the area of Krapina.

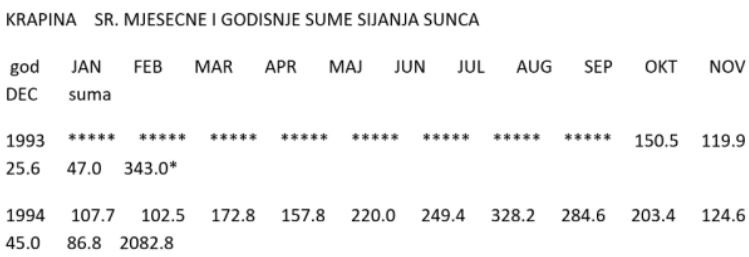

Figure 8. Data from DHMZ for the area of Krapina

The approximate quantity of electric power that can be obtained by using solar panels at the most convenient surfaces (Photovoltaic-software 2017) has been calculated on the basis of DHMZ data and of average efficiency of solar panels (Kelly-
Detwiler, 2017). According to Photovoltaic-software (2017), the real quantity of energy obtained per $\mathrm{m}^{2}$ at the annual level is:

$$
e / m^{2}=\operatorname{solar} \cdot \frac{v_{\text {sunce }}}{v_{\text {dan }}} \cdot \text { efikasnost }
$$

$$
\begin{aligned}
& e / m^{2}=\operatorname{solar} \cdot \frac{v_{\text {sunce }}}{v_{\text {dan }}} \cdot \text { efikasnost } \\
& =1900 \mathrm{kWh} / \mathrm{m}^{2} \cdot \frac{2079.7 \mathrm{~h}}{4380 \mathrm{~h}} \cdot 0.17 \\
& =153.4 \mathrm{kWh} / \mathrm{m}^{2}
\end{aligned}
$$

Although additional climate factors should be taken into consideration for a more detailed calculation, it is already visible that the solar potential is very significant and that its usage should be promoted. An average household in Croatia consumes $3000 \mathrm{kWh}$ of electric power per year. Hence, the installation of about $19,6 \mathrm{~m}^{2}$ of solar panels would cover the annual needs of one household a year. Since an average residential house in Sveti Križ Začretje (with a slope roof) has one side of the roof being $60 \mathrm{~m}^{2}$ large, it can be implemented.

\section{CONCLUSION}

The application of high-quality $3 \mathrm{D}$ model is very important in planning smart cities, and it is presented here through the analysis of solar potential of roofs in the test area of the locality Sveti Križ Začretje. The obtained results have shown that it is possible to meet the needs of a household (family house) for electric power at the annual level by using solar panels. It should be pointed out here that the analyses based on DSM are relatively simple and completely automatic due to regular structure of the model.

The usage of renowable sources of energy as the energy of sun, wind, sea and other is therefore primarily an economic issue today, i.e. the issue of the price of producing $1 \mathrm{kWh}$ of energy. The share of energy obtained from carbohydrates will be reduced in the future, and the energetic strategy that will be applied in 50 years is an issue that should be considered even today.

\section{ACKNOWLEDGEMENTS}

We thank the Meteorological and Hydrological Service of the Republic of Croatia for the climate data given to us, and to the companies AMG Studio and GEO LEGIN for the support and instruments provided. 


\section{REFERENCES}

Agugiaro, G., Nex, F., Remondino, F., De Filippi, R., Droghetti, S., Furlanello, C., 2012. Solar radiation estimation on building roofs and web-based solar cadastre, XXII ISPRS Congress, Melbourne, Australia, 1.9.2012., http://www.isprsann-photogramm-remote-sens-spatial-inf-sci.net/I2/177/2012/isprsannals-I-2-177-2012.pdf.

Cetl, V., Tomić, H., Lisjak, J., 2013. Primjena 3D modela u upravljanju gradom, Studija, Geodetski fakultet, Sveučilište u Zagrebu, Zagreb.

Dimova, S., 2010. The Role of Geoinformation in Disaster Management. Kartografija i geoinformacije, 9 (14), 46-57.

Gorički M., 2015. Moderne tehnologije u funkciji pametnih gradova, Diplomski rad, Geodetski fakultet Sveučilišta u Zagrebu.

Kelly-Detwiler P., 2017. As Solar Panel Efficiencies Keep Improving, It's Time To Adopt Some New Metrics, https://www.forbes.com/sites/peterdetwiler/2013/07/16/assolar-panel-efficiencies-keep-improving-its-time-to-adoptsome-new-metrics/\#32d80301f39c, (23 May 2017).

EC 2017, 2030 Energy Strategy,

http://ec.europa.eu/energy/en/topics/energy-strategy-andenergy-union/2030-energy-strategy, (07 August 2017).

Photovoltaic-software 2017. How to calculate the annual solar energy output of a photovoltaic system?, http://photovoltaicsoftware.com/PV-solar-energy-calculation.php, (23 May 2017).

Poslončec-Petrić, V., Vuković, V., Frangeš, S., Bačić, Ž., 2016a. Voluntary Noise Mapping for Smart City, ISPRS Annals of Photogrammetry, Remote Sensing and Spatial Information Sciences, Volume IV-4/W1, 2016, pp.131-137.

Poslončec-Petrić, V., Šlabek, L., Frangeš, S., 2016b. With the Crowdsourced Spatial Data Collection to Dynamic Noise Map of the City of Zagreb, International Symposium on Engineering Geodesy SIG 2016, Croatian Geodetic Society, pp. 411-426.

Protić, D., Nestorov, I., Vučetić, I., 2014. 3D Urban

Information Models in making a "smart city" - the i-SCOPE project case study, Geonauka Vol. 2, No. 3, 12-16.

Wikipedia, 2017. Solar energy in the European Union, https://en.wikipedia.org/wiki/Solar_energy_in_the_European_U nion\#cite_note-BaroPhoto2015-14, (16 May 2017).

UN, 2014. World Urbanization Prospects, Organization of United Nations, http://esa.un.org/unpd/wup, (6 May 2017).

UN, 2015. World Urbanization Prospects The 2014 Revision, Department of Economic and Social Affairs, Population Division, https://esa.un.org/unpd/wup/Country-Profiles/, (7 May 2017). 